\title{
Status of Marine Current Energy Conversion in China
}

\author{
Hongwei Liu and AbuBakr S Bahaj
}

\begin{abstract}
Marine current energy conversion (MCEC) technologies are promising renewable energy systems with some full scale and semi-commercial turbines constructed and deployed in several countries around the world. In this work, we present the status of marine current energy and systems in China and policies geared to support these. Over the past ten years the Chinese government has provided a policy framework and financial supports for the development of MCEC technologies of various design philosophies which has resulted in significant technology deployment at sea. A review of these technologies - which have turbine capacities in the range $20 \mathrm{~kW}$ to $650 \mathrm{~kW}$, mostly tested at sea - is presented in the paper. In addition, the paper also discusses Chinese plans for marine energy test sites at sea to support prototype development and testing and concludes with a view of future prospects for the marine energy technology deployment in China.
\end{abstract}

Keywords - marine energy, marine turbines, tidal current energy, tidal energy in China.

\section{INTRODUCTION}

$\mathrm{M}$ arine currents in the oceans driven by gravitational effects possess large kinetic energy which can be harnessed for electricity power generation. The principle of marine current energy conversion is in most cases similar to that of wind energy, where horizontal axis turbines can be used to capture the sea water flow in marine currents and covert that into electrical power using similar but adapted technologies as wind turbine generators. However, marine currents (sometimes also known as tidal stream) as a resource have different characteristics than the wind energy resource. Tidal

Manuscript received 23 February, 2021; revised 21 April, 2021; accepted 13 May, 2021; published 20 May, 2021.

This is an open access article distributed under the terms of the Creative Commons Attribution 4.0 licence (CC BY http://creativecommons.org/licenses/by/4.0/). unrestricted use (including commercial), distribution and reproduction is permitted provided that credit is given to the original author(s) of the work, including a URI or hyperlink to the work, this public license and a copyright notice.

This article has been subject to single-blind peer review by a minimum of two reviewers. This work was supported by National Key Research and Development Program (2018YFB1501900), currents have a density which is approximately 800 times that of air utilised in wind energy conversion, it is limited by the depth of where the resources occur and it is more predictable than most other renewable energy resources. Marine currents mainly result from the gravitational motion of the moon and the earth and therefore are not weather dependent. The resources are regular, predictable providing a more favourable resource for energy exploitation and planning [1, 2]. This also provides an advantage for power purchase agreements compared to all renewable energy systems, with the exception of hydropower. Hence, marine current energy conversion (MCEC) is expected to be a promising renewable technology which can be integrated into national grid system in a coherent way [3]. Furthermore, in the past two decades, there is already great and rapid progress being made all over the world with first multi-megawatt arrays already producing power $[4,5]$. These arrays were built on a commercialisation progression pathway including some projects with full scale or semi-commercial turbines that were constructed and deployed, such as Seagen by Marine Current Turbines in UK (twin-rotor, $16 \mathrm{~m}$ diameter each rated at $600 \mathrm{~kW}$, decommissioned in 2018) [6], $1.5 \mathrm{MW}$ turbine (18.4 $\mathrm{m}$ in diameter) by Hammerfest in Norway [7], and 1.5 MW (AK1500), 2 MW turbines by Simec Atlantis in UK [4]. The most significant commercial deployment is the Meygen project in which phase 1 has resulted in the deployment of $4 \mathrm{MW}$ array in 2018 which is part of an ambitious $398 \mathrm{MW}$ capacity to be constructed during the next 5 years [4]. Such commercial work is built on and augmented with significant and pioneering fundamental research especially in the UK and elsewhere

the National Science Foundation of China (No.51575477, No. 51775487), and Fundamental Public Welfare project of Zhejiang Province (LGF19E050004). It is also supported by EPSRC grant $\mathrm{EP} / \mathrm{K} 012347 / 1$, International Centre for Infrastructure Futures (ICIF).

H. Liu is with the School of Mechanical Engineering, State Key Laboratory of Fluid Power and transmission, Zhejiang University, Hangzhou, China, 310027 (e-mail: zju000@163.com).

A. S. Bahaj is with the Energy and Climate Change Division within the Faculty of Engineering and Physical Sciences at the University of Southampton, Boldrewood Innovation Campus, SO16 7QB, UK (email:A.S.Bahaj@soton.ac.uk). Digital Object Identifier https://doi.org/10.36688/imej.4.11-22 
[8-14].

In recent years, China has given much more attention to the renewable energy, including wind energy (onshore and offshore), solar energy, marine (ocean) energy, biomass energy and geothermal energy. Marine energy exploitation in China is mainly through research on tidal stream energy with some work being conducted on wave energy since the early 1980s [15, 16]. The research has progressed slowly until 2000s, which can be mainly attributed to the technology readiness level. With the maturing of wind turbine technologies and propelled by the environment consideration and a required diversity strategies of energy security, as well as carbon emission reduction, more attention and financial supports was given to the MCEC technologies by Chinese government, with rapid progress being made since 2005. In this paper, we review this progress and make reference to Chinese policy related to marine energy. This is followed by an overview of the status of marine current energy conversion technologies in China focusing on significant sea tested medium-scaled turbines. An overview of plans for marine energy test sites will also be briefly presented. The paper will conclude with a view of the future prospects for future marine energy technology deployment in China.

\section{MARINE CURRENT RESOURCES AND POLICY PERSPECTIVE} IN CHINA

\section{A. Marine current energy resource in China}

The intensity of the marine current resource in China is variable. According to published investigation of 130 channels in 1989, the theoretical power of marine current energy resources in China was estimated to be about 1.4 GW (Table 1). This excludes un-investigated sea area which may possess strong currents [17-19]. As can be seen from Table 1 and the sites locations map Fig.1, marine current energy resource is distributed unevenly across China and most of the tidal current energy is concentrated in three coastal regions which are north of the Yellow sea, East Sea and South Sea respectively. Among these is the potential theoretical capacity of marine current energy in Zhejiang is about $709 \mathrm{MW}$ and the power density of some channel in the range $15-30 \mathrm{~kW} / \mathrm{m}^{2}$, especially the Jintang channel, Guishan channel and Xihou channel in the Zhoushan archipelago, whose average power density is above the $20 \mathrm{~kW} / \mathrm{m}^{2}$ and it is very suitable for exploitation.

\section{B. China support policy for marine energy}

Under the background of sustainable development and urged by the need for high quality environments, the $13^{\text {th }}$ Five-Year Plan for Marine Renewable Energy (2016-2020) of China released by State Oceanic Administration (SOA) in 2016, proposed an over-arching vision of ocean energy. That is to promote the demonstration and application of marine renewable energy and improve the technology readiness levels, with a focus on the breakthroughs in key technologies. In this plan, the construction of 4 national offshore ocean energy test and demonstration districts was firstly put forward, which were scheduled to be finished by 2020 .

In 2019, a first temporary feed-in tariff for a marine current turbine project led by a company called LHD (which will be introduced later) was set up by Zhejiang Province Development and Reform Commission and approved by National Development and Reform Commission of China. The tariff was set at 2.58 Yuan $\mathrm{RMB} / \mathrm{kWh}$ (about USD0.385/kWh) and was applicable to the Jiaxia tidal power station of China [20]. Due to the limited number of marine current power stations and their high present cost, the National Energy Administration (NEA) didn't make this tariff available nationally, but allowed the pricing mechanisms to be set at to local government level [21].

In 2016, NEA and National Development and Reform Commission (NDRC) jointly released Strategy to Energy Production and Consumption (2016-2030) aiming to push forward the demonstration and development of marine energy technologies [22]. Also in 2016, NEA released Energy Technology Innovation for $13^{\text {th }}$ Five-Year Plan, and key technologies of ocean energy and demonstration of such technologies was stressed in the plan [23]. In the plan ocean energy technologies exclude offshore wind and were defined as wave energy, tidal energy, marine current energy and ocean thermal energy conversion. The first three of these were targeted for deployment and demonstration. Furthermore, the Ministry of Science and Technology (MOST) added marine energy into its strategy research field of 2035 medium-long term science and technology development in order to enhance the support of marine energy converter development [24]. In the recently published $14^{\text {th }}$ five year's plan and 2035 Vision drafted by Zhoushan City, distributed solar energy, wind energy and marine current energy were specifically put forward in the plan [25].

In 2018, Guidance on Improving and Strengthening Financial Services for Marine Economic Development was jointly issued by the People's Bank of China, SOA and NDRC for promoting and advancing marine energy demonstration projects and their commercialisation. In this guidance, bank loans, equity and debt financing, insurance service, etc. were facilitated to support the development of marine energy.

Keeping in step with the above policy releases, some funding schemes for marine energy research and development were established. The National Key Research and Development Program of China provided around 80 million RMB (about USD11.9 million) starting from 2010 until now. This support is aimed at solving some key fundamental understanding including the device design, off-grid electricity supply, technology development, and multi-energy comprehensive utilisation [24, 26] where integrated power supply systems, consisting of ocean energy, offshore wind energy, solar energy and energy storage batteries were researched. 
TABLE I

MARINE CURRENT ENERGY DISTRIBUTION IN CHINA IN 1989

\begin{tabular}{|c|c|c|c|c|}
\hline \multirow[t]{2}{*}{ China region } & \multicolumn{3}{|c|}{ Velocity distribution $\mathrm{Vm}(\mathrm{m} / \mathrm{s})$} & \multirow{2}{*}{$\begin{array}{l}\text { Theoretical } \\
\text { Power } \\
(\mathrm{MW})\end{array}$} \\
\hline & $\mathrm{Vm} \geqq 3.06$ & $2.04 \leqq \mathrm{Vm}<3.06$ & $1.28 \leqq \mathrm{Vm}<2.04$ & \\
\hline Liaoning & North of Laotieshan & & Changshan East Channel, Guapi & 113.05 \\
\hline Province & Channel & & $\begin{array}{l}\text { Channel, Sanshan and Xiaosanshan } \\
\text { Channel }\end{array}$ & \\
\hline $\begin{array}{l}\text { Shandong } \\
\text { Province }\end{array}$ & & North of Beihuangcheng Island & $\begin{array}{l}\text { Channels in Temple Archipelago } \\
\text { and Eastern Coast }\end{array}$ & 117.79 \\
\hline $\begin{array}{l}\text { Estuary of } \\
\text { Yangtze River }\end{array}$ & & $\begin{array}{l}\text { North Harbour and South } \\
\text { Trough }\end{array}$ & $\begin{array}{l}\text { Hengsha Harbour and North } \\
\text { Trough }\end{array}$ & 30.49 \\
\hline $\begin{array}{l}\text { Zhejiang } \\
\text { Province }\end{array}$ & $\begin{array}{l}\text { Jintang, Guishan and } \\
\text { Xihou Channels, etc. } \\
\text { North of Hangzhou Bay }\end{array}$ & $\begin{array}{l}\text { Some channels in Zhoushan and } \\
\text { Estuary of Jiaojiang }\end{array}$ & $\begin{array}{l}\text { Some channels in Zhoushan, } \\
\text { Xiangshan Harbour, Sanmen Bay, } \\
\text { Taizhou and Leqing Bay }\end{array}$ & 709.03 \\
\hline $\begin{array}{l}\text { Fujian } \\
\text { Province }\end{array}$ & $\begin{array}{l}\text { Northwest of Sandu Cape } \\
\text { in Sanduao }\end{array}$ & $\begin{array}{l}\text { East of Sandu Island, Estuary of } \\
\text { Mingjiang, south of Haitan Strait } \\
\text { and Dazuo Channel }\end{array}$ & $\begin{array}{l}\text { Shacheng Harbour, Xinghua Bay, } \\
\text { and some channels in Haitan Strait }\end{array}$ & 128.05 \\
\hline Taiwan & & $\begin{array}{l}\text { North and south of Penghu, } \\
\text { North of Taiwan, North of } \\
\text { Linshanbi }\end{array}$ & $\begin{array}{l}\text { Penghu Island, West of Taiwan, } \\
\text { Northeast of Sandiaojiao }\end{array}$ & 228.25 \\
\hline $\begin{array}{l}\text { Guangdong } \\
\text { Province }\end{array}$ & & $\begin{array}{l}\text { East mouth of Qiongzhou strait, } \\
\text { and Wailuo Channel }\end{array}$ & $\begin{array}{l}\text { Pearl River Estuary, channels in } \\
\text { western coast of Guangdong }\end{array}$ & 37.66 \\
\hline $\begin{array}{l}\text { Hainan } \\
\text { Province }\end{array}$ & & $\begin{array}{l}\text { South Channel of East mouth of } \\
\text { Qiongzhou Strait }\end{array}$ & Chengmai Estuary, Yinggehai & 28.24 \\
\hline & & & Total & 1394.85 \\
\hline
\end{tabular}

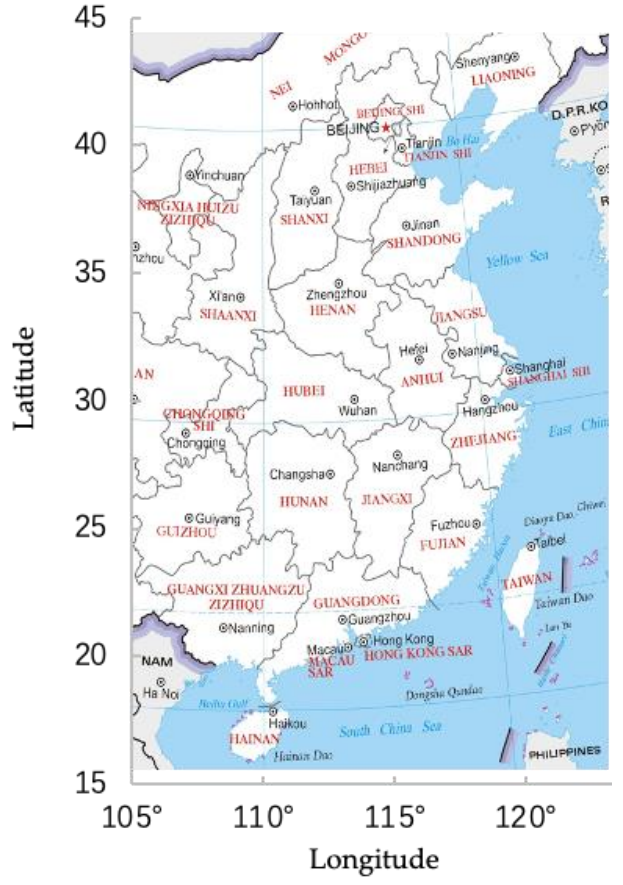

Fig. 1. Test side locations East of China as detailed in Table 1.

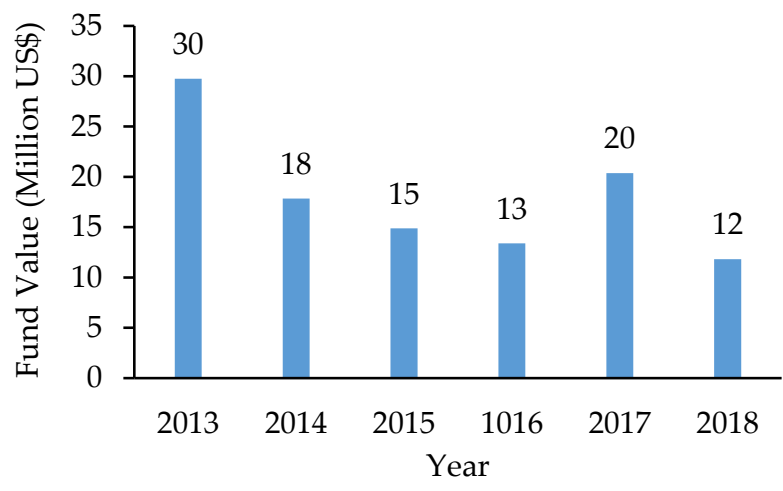

Fig. 2. Funding under the Chinese Marine Renewable Energy Special Fund (CMRESF)

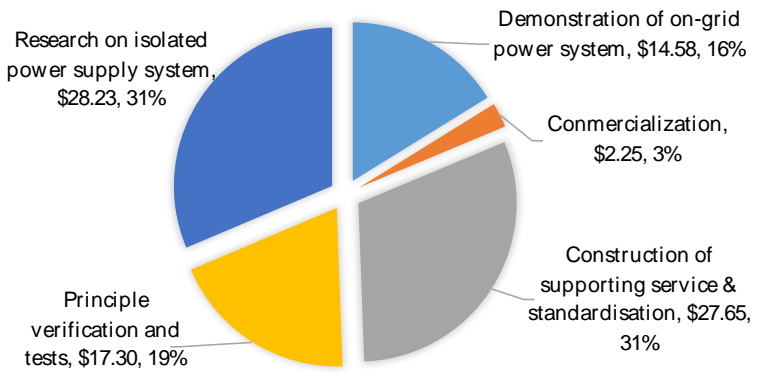

Fig. 3. Supported marine energy areas from 2010 to 2012 by the Chinese Marine Renewable Energy Special Fund (CMRESF). 


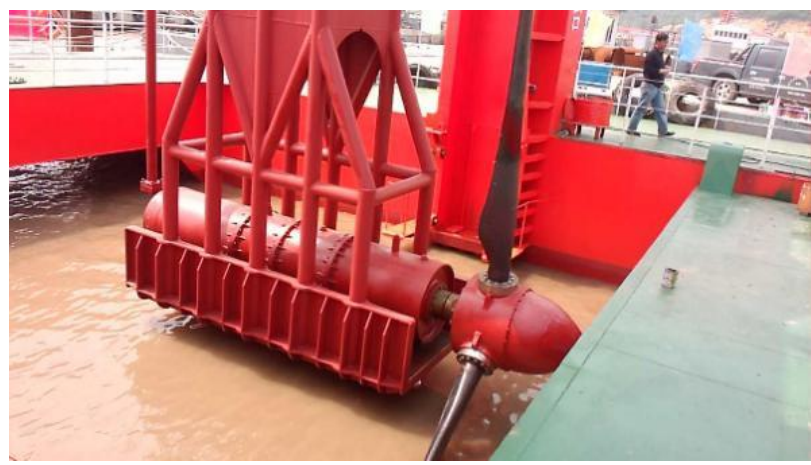

Fig. 4. $60 \mathrm{~kW}$ turbine demonstrating off and on grid operation.

In 2010, there was a milestone for the development of marine energy in China. The Chinese Marine Renewable Energy Special Fund (CMRESF) was established by State Oceanic Administration (Fig.2). Up to 2019, over 1.3 billion RMB (US\$ 0.19 billion) and 114 projects have been arranged specifically targeting marine energy technologies and project development [27]. The research and development programme are focused on two areas (i) resource assessment and fundamental research to improve the performance of marine energy converters and (ii) development of full-scale turbines, the demonstration of their performance at sea and final commercialisation. Within these two areas specific support is targeted into 5 categories - resource assessment and standardisation, technology research and its demonstration, isolated power supply systems' demonstration, on-grid large scale marine current turbine (MCT) development and demonstration, and commercialisation deployment (Fig.3).

In addition, in 2016, the National Natural Science Foundation of China (NNSFC) provided financial support for ocean energy with a budget of around 6 million RMB (US\$ 0.9 million) which supported 18 projects. Other governmental sectors such as the National Energy Administration provided over 50 million RMB (about US\$ 7.46 million) funding to support the creation of the State Key Laboratory of National Tidal Ocean Energy Power Generation in 2011.

Before 2018, the calls for proposals were publicly released on an annual basis and qualified institutions can apply or bid in any of the five target areas (Fig.3). At the early stages of the programme, there were too many projects, and most were granted around 3 million RMB (US\$ 0.45 million). With development and technologies convergence, more funding by the programme was targeted to full scale turbine demonstration resulting in more money for each project at the expense of smaller size projects [16]. At the same time the support programme was inclined to support institutions with better research facilities and fundamental understanding. However, in 2019 this funding has stopped and no further announcement was made of plans for future programmes.

Such government financial support played a vital role in promoting the development of marine current energy technologies in China. Under such support, important

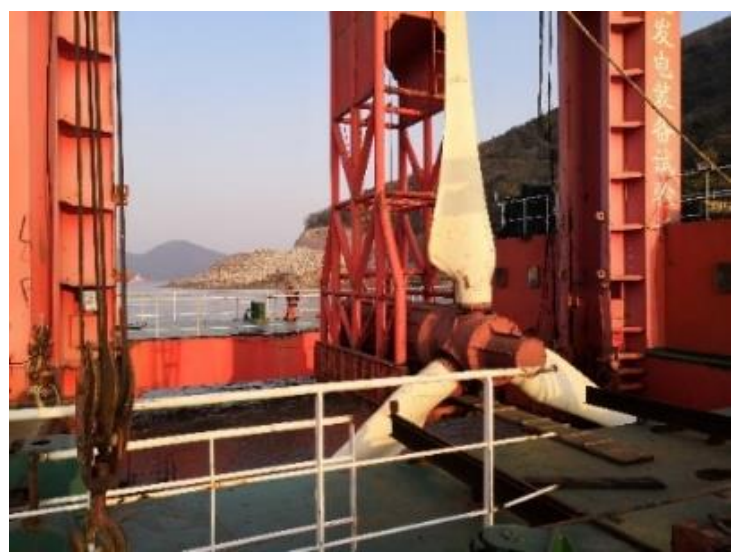

Fig. 5. $120 \mathrm{~kW}$ hydraulic pitchable turbine on it platform.

milestones were achieved for marine current turbine research, including the developments \& deployments of turbines with capacities ranging from $2 \mathrm{~kW}$ to $650 \mathrm{~kW}$, as well as plans of construction of ocean test sites.

\section{STATUS OF MARINE ENERGY TECHNOLOGIES IN CHINA}

Despite the early start of marine current energy research in China in 1970's, not much progress was made until the 2000s. Since then, the research mainly focused on fundamental understanding of vertical-axis marine current turbines (MCT) at capacities below $100 \mathrm{~kW}$ some of which were tested at sea.

From the year 2004, institutions such as Zhejiang University, Northeast Normal University started to undertake research on horizontal axis marine current energy conversion technologies supported by the high science technologies projects of China (863 plan) [28, 29], and the National Natural Science Foundation of China [30]. From 2010 the Chinese Marine Renewable Energy Special Fund was established resulting in more industrial companies and institutions to join the research effort on marine current energy conversion [31]. These include Guodian United Power Corporation (GUPC), Harbin Electric Corporation (HEC), HangZhou JiangHe Hydro-Electric Science \& Technology Co. Ltd (HZJH) and Three Gorges Corporation of China (TGC). Similar to the development trend in the world, the focus was centred on horizontal axis marine current turbines to exploit marine current energy in China due to their high efficiency and good starting performance.

\section{A. Horizontal axis turbine technologies}

Over the last ten years, some remarkable progress of horizontal axis marine current turbines was achieved in China. This includes the sea trails and operation of the $650 \mathrm{~kW}$ and the $300 \mathrm{~kW}$ by Zhejiang University (ZJU) in 2017/18, and those by GUPC, HZJH and HEC as detailed below.

\section{1) Research and Development}

Zhejiang University (ZJU) marine current technology research started in 2004 focusing mainly on the horizontal axis marine current turbines. A series of such turbines have been developed and tested by ZJU [32-34]. 


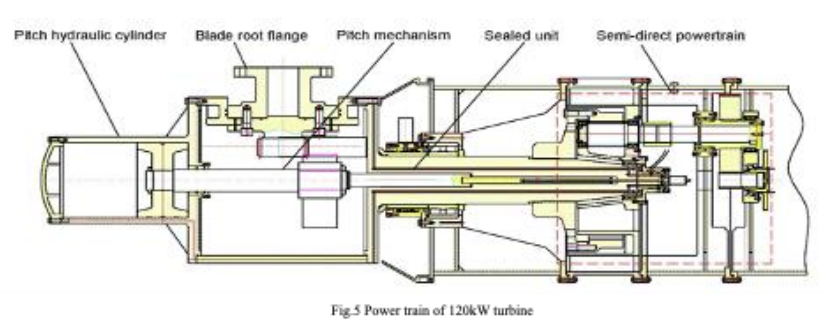

Fig. 6. Power train of $120 \mathrm{~kW}$ turbine of Fig.5.

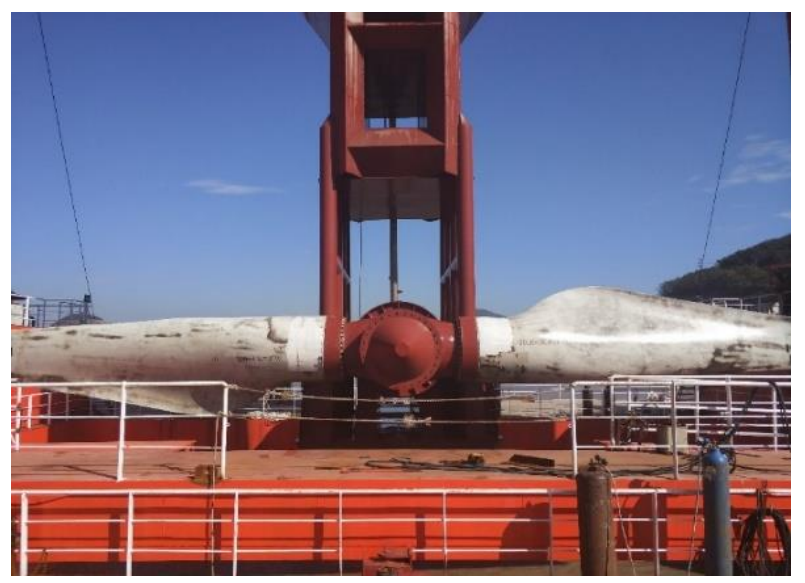

Fig. 7. $650 \mathrm{~kW}$ horizontal axis turbine by ZJU.

In 2005, a $5 \mathrm{~kW}$ prototype was designed based on wind turbine experiences to validate the feasibility of marine current turbine technologies, including the blade design, power transmission and sealing system. This was followed by a $25 \mathrm{~kW}$ semi-direct drivetrain turbine and $20 \mathrm{~kW}$ hydraulic transmission turbine in 2009 under the supports of Science and Technology Development Projects [30]. In 2010 and through support by the Chinese Marine Renewable Energy Special Fund, a $60 \mathrm{~kW}$ turbine was developed and in May 2014 a floating deployment platform was constructed and commissioned(Fig.4). The generated electricity was partly stored in batteries situated on the platform and then inverted to AC electricity for lightings and powering other equipment on the floating platform. Excess power was dumped into a resistor bank. In 2015, the turbine was updated to allow connection to the grid. This $60 \mathrm{~kW}$ turbine has a starting speed in the range 0.6$0.7 \mathrm{~m} / \mathrm{s}$ [34] and generates its rated power at about $1.9 \mathrm{~m} / \mathrm{s}$.

In order to improve the reliability of the power transmission system and reduce the risk of high-speed stages, a semi-direct power train and a low-speed permanent magnet synchronous generator (PMSG) was used. The reliability of these two components was verified through the five years operation. The understanding, design approach and developed mechanisms were used to inform the development of two new $300 \mathrm{~kW}$ turbines respectively by Guodian United Power Corporation, Harbin Electrical Corporation and $120 \mathrm{~kW}$ and $650 \mathrm{~kW}$ turbines developed by ZJU. In all these turbines, the sealing system used, consists of a three layers of sealing rings and a wiper rings to protect the bearing from the sands

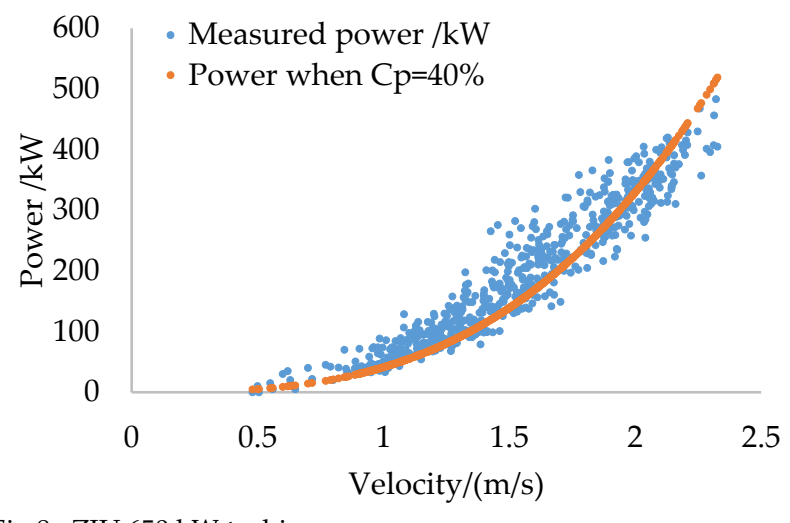

Fig.8. ZJU $650 \mathrm{~kW}$ turbine power curve.

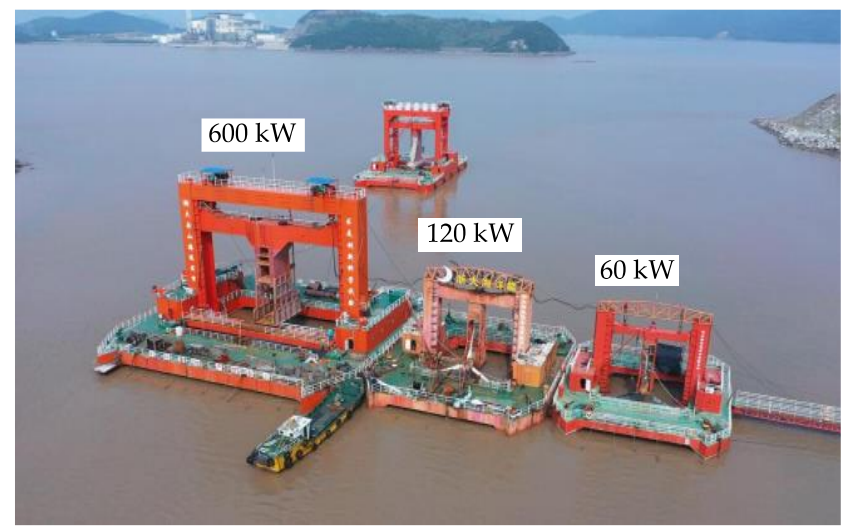

Fig.9. MCEC test station constructed by ZJU.

contained in the sea water. The chamber of the gearbox was filled with pressurised oil to realise the equalisation of inside and outside pressures.

In 2015, a hydraulic pitchable $120 \mathrm{~kW}$ grid connected horizontal axis marine current turbine was deployed, as shown in Fig.5, representing the first grid-connected marine current energy conversion turbine in China [35]. The hydraulic pitch system made it possible for the turbine to control output power and operate in bidirectional flow. The semi-direct drive technology was also used, but in order to provide space for pitch actuator, a shunt and confluence power mechanism was adopted, and the hydraulic actuator was put ahead of turbine (Fig.6).

Building on the progress made above, ZJU developed a grid-connected fix-pitched $650 \mathrm{~kW}$ turbine which was successfully tested in 2017. Currently, this is the largest marine current horizontal axis turbine in China (Fig.7). ZJU are currently developing a more improved pitching system which will be deployed in 2021. The test results are shown in Fig.8 including the value of the maximum power coefficient of the turbine, determined to be above 0.4 . This success was attributed to the maximum power point tracking control strategy, as can be seen in Fig.8.

A marine current testing station based in the science demonstration island - Zhairuoshan island, with 4 test berths (floating platform), Fig.9, was also constructed in Zhoushan City, Zhejiang Province. The station is equipped with hoisting machine and moving maintenance deck, and any required daily maintenance 


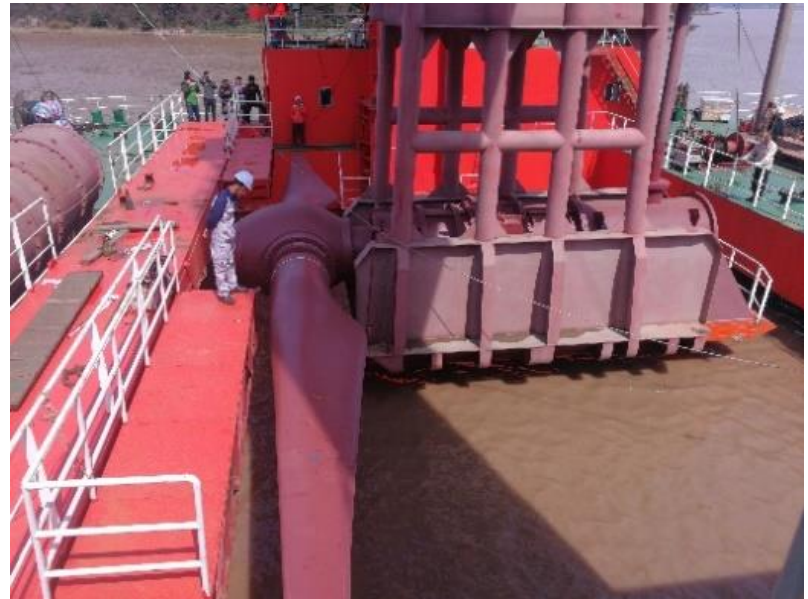

Fig.10. $300 \mathrm{~kW}$ turbine by GUPC \& ZJU.

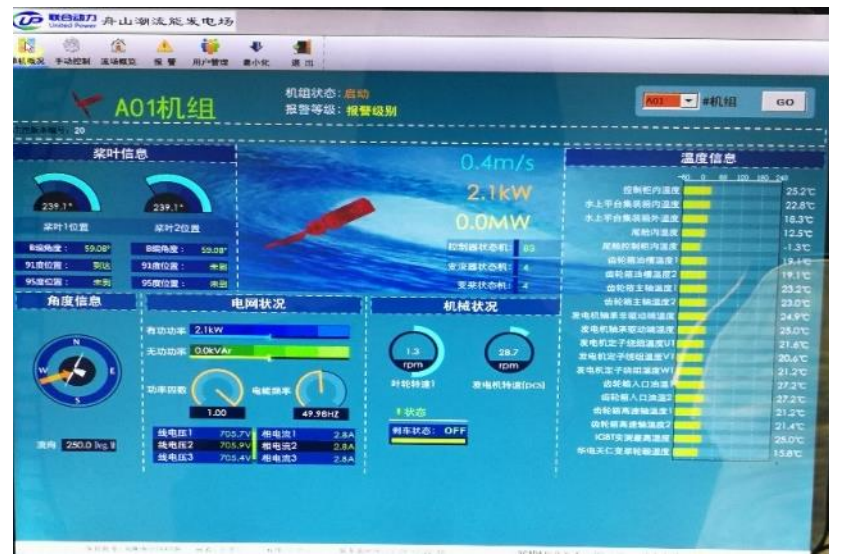

Fig.11. Monitoring and control screen of $300 \mathrm{~kW}$ turbine of Fig.10.

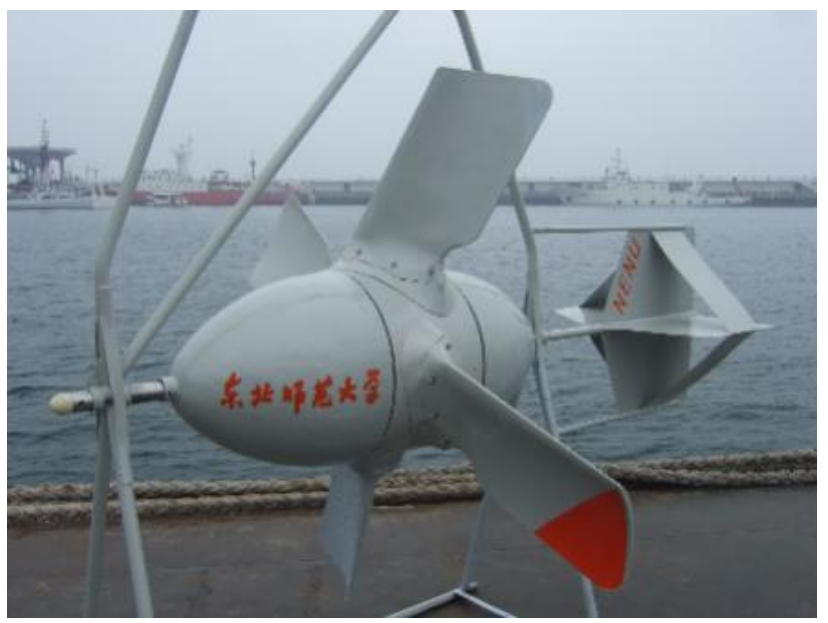

Fig.12. $2 \mathrm{~kW}$ multi-blade turbine by NNU.

can be accomplished on the deck. The necessary grid connection equipment for the devices was also provided on the platform. The generated $400 / 690 \mathrm{~V}$ voltage is stepped-up to $10 \mathrm{kV}$, then transmitted to grid access point of the island. Depending on the capacity of turbines, adopted power electronic devices were different. For the $650 \mathrm{~kW}$ turbine, a full power converter was adopted just like a wind turbine. The $120 \mathrm{~kW}$ and $60 \mathrm{~kW}$ turbines, due to their small capacity, uncontrolled rectifiers were used, and the power control were realised through the look-up table predefined between power and voltage.

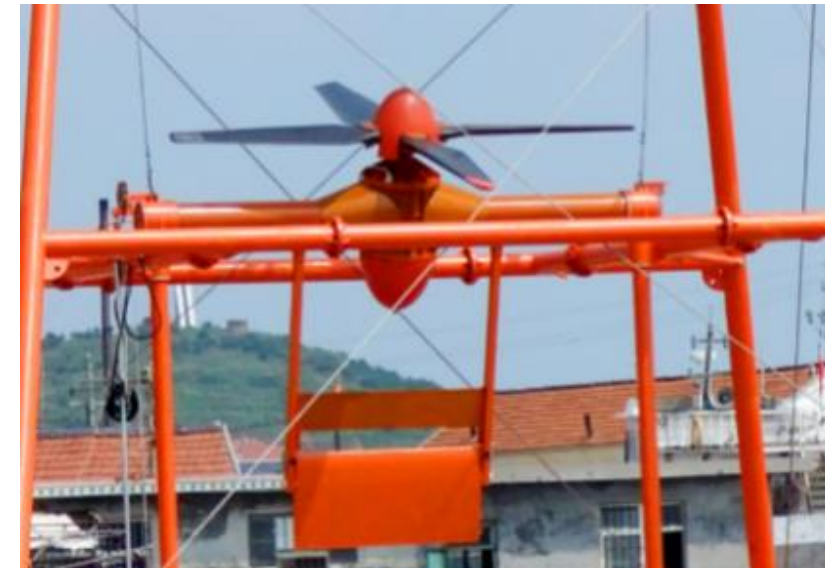

Fig.13. $20 \mathrm{~kW}$ direct-drive horizontal axis turbine by NNU.

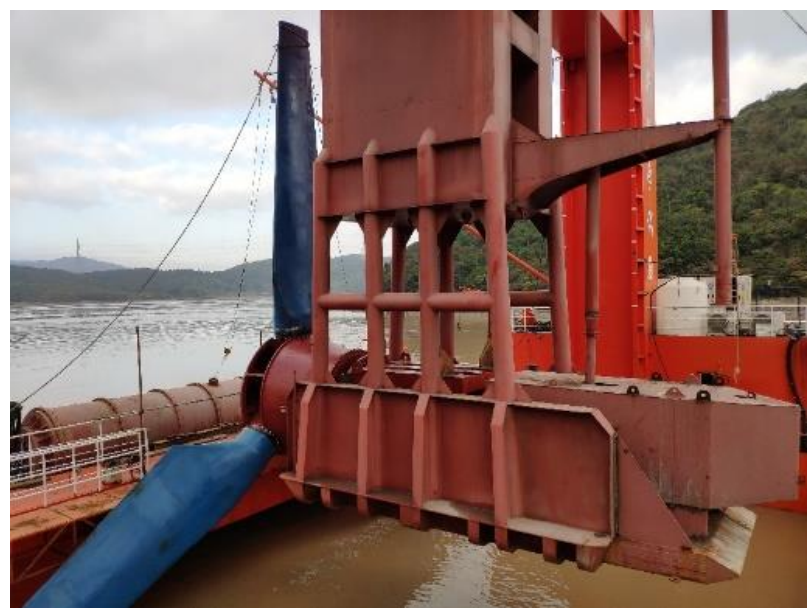

Fig.14. $300 \mathrm{~kW}$ horizontal axis turbine by NNU and HJHE.

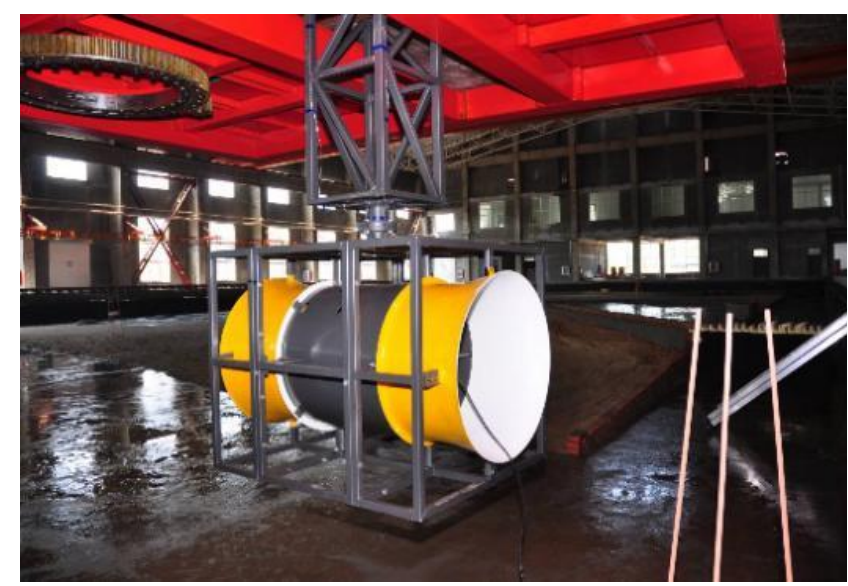

Fig.15. $20 \mathrm{~kW}$ OUC ducted turbine in tank tests.

\section{2) Route to commercialization}

In order to bridge the gap between research and commercialisation, ZJU cooperated with Guodian United Power Corporation, who is also a Chinese wind turbine manufacturer, to develop a $300 \mathrm{~kW}$ marine current turbine (Fig.10). The project was funded by the Chinese Marine Renewable Energy Special Fund in 2013 with the aim to find a technical path of industrialisation and commercial prototypes. The $300 \mathrm{~kW}$ turbine was built, and testing at sea started in March 2018 and completed in April 2019. The turbine achieved its full power of $300 \mathrm{~kW}$ at current speed of $1.9 \mathrm{~m} / \mathrm{s}$. 


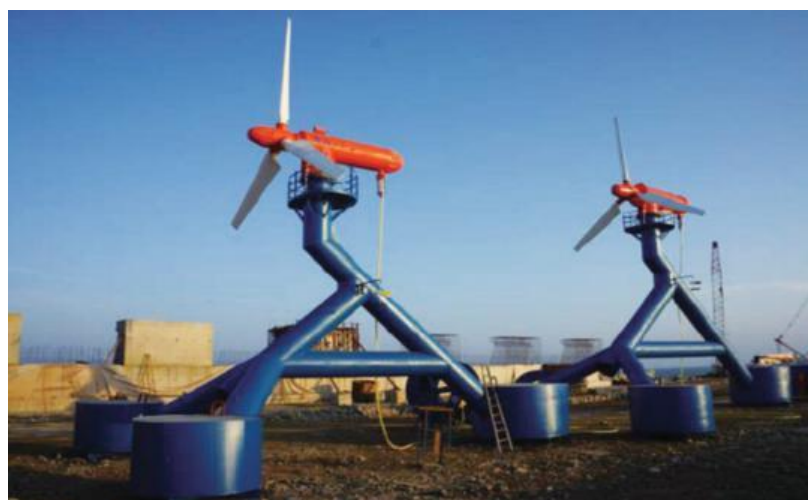

Fig.16. 2 turbines each rated at $50 \mathrm{~kW}$ gravity based developed by OUC for the micro grid project.

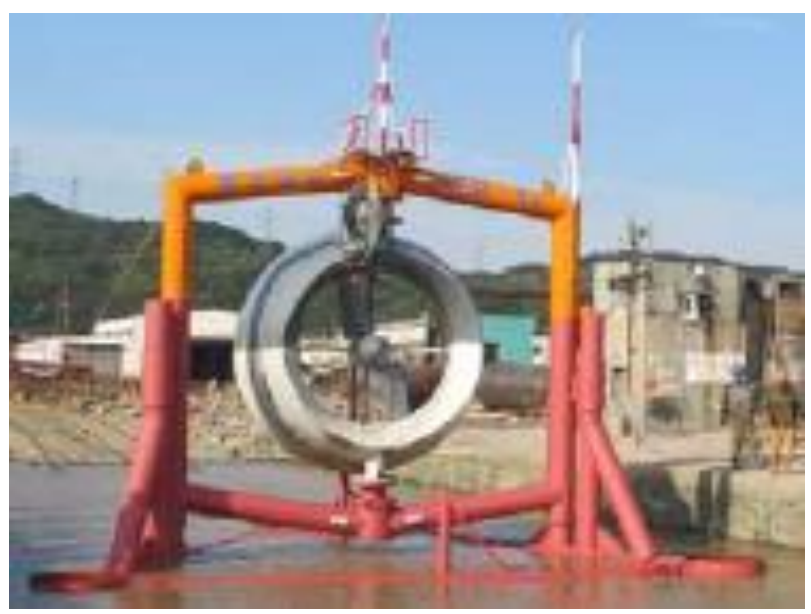

Fig.17. $10 \mathrm{~kW}$ horizontal axis turbine by HEU and HEC.

In its design, the $300 \mathrm{~kW}$ turbine also adopted the above mentioned semi-direct power drivetrain and an individual electrical pitch system which can drive each blade to rotate in the range of $270^{\circ}$. This pitch angle range enabled the blade to be feathered whenever the flow velocity starts to exceed the rated power regardless of the flow direction. The pitching system consists of a pitch controller, electrical driven motor and gearbox, pitch sensor and batteries housed in the hub. The hollow main shaft made it possible for the signal cables to link the hub devices to the control console. All signals of the equipment, including the state signals of gearbox, electrical system and pitch in the hub, were transmitted to the monitoring hub located at the end of generator.

A SCADA (supervisory control and data acquisition) system and monitoring were also used to monitor the pitch system, rotating shafts, generator, and brake system, etc. as shown Fig.11.

The research in Northeast Normal University (NNU) was mainly focused on devices appropriate for the lowspeed tidal current flows. A $1 \mathrm{~kW}$ prototype turbine was completed and tested in 2005, followed by a $2 \mathrm{~kW}$ directdriven turbine in 2009 and a $20 \mathrm{~kW}$ direct-driven horizontal axis marine current turbine in 2013. The research developed some new methods to improve starting performance and power transmission efficiency. These include multi-blades, direct-drive turbines and polymer bearing with water lubrication technology, stator coils pouring technology etc. It was

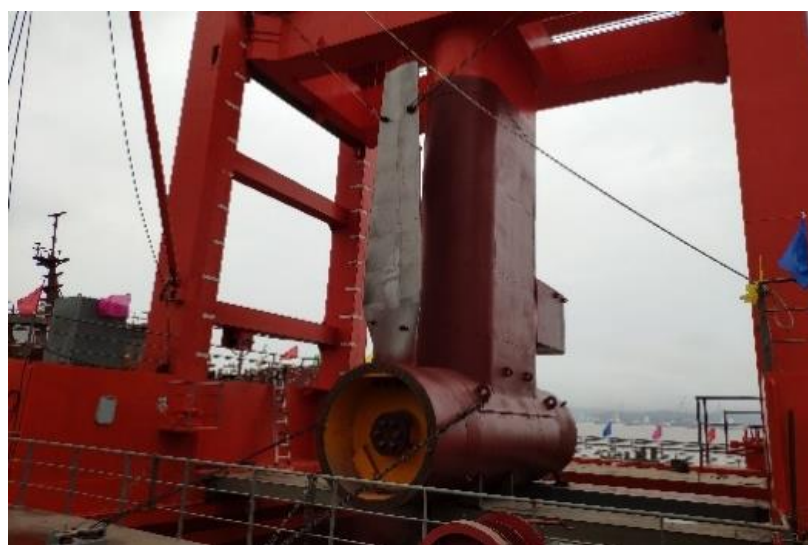

Fig.18. $300 \mathrm{~kW}$ horizontal axis turbine by HEC and HEU.

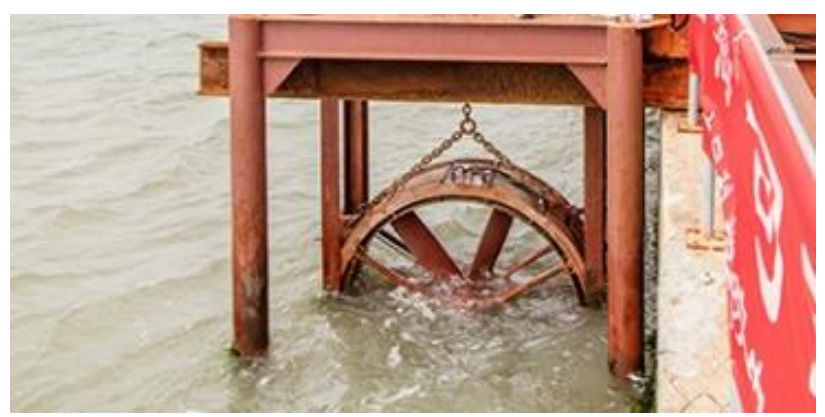

Fig.19. Twin $2.5 \mathrm{~kW}$ horizontal axis developed by IEE of CAS.

reported some of these turbines can start to rotate at about flow velocities as low as $0.25 \mathrm{~m} / \mathrm{s}[36,37]$.

Fig.12 depicts the $2 \mathrm{~kW}$ turbine with 4 blades optimised for capturing low velocity flows from the sea water column with reported total efficiency (including power coefficient and generator efficiency) of about 0.2 . It was supported by the 863 projects programme [37], which was aimed at improving turbine starting performance and underwater seal technology. The $20 \mathrm{~kW}$ direct-driven turbine shown in Fig.13 was supported by the National Science \& Technology Support Plan Projects with the aim of solving the key problems encountered in long-term in-situ operation and maintenance $[36,38]$. The turbine was designed to be free to rotate around the centre beam allowing the turbine to align itself autonomously with flow direction. During 2013, the turbine was tested at sea in Zhaitang island Shandong Province for half a year and the results showed that the turbine could start at around $0.7 \mathrm{~m} / \mathrm{s}$.

Building on the knowledge gained, in 2019 NNU and HZJH jointly developed a $300 \mathrm{~kW}$ turbine, supported by the Chinese Marine Renewable Energy Special Fund [39]. The developed turbine (Fig.14) has the same design philosophy as described in the previous section. That is, it uses a direct drive powertrain (without gearbox), an external outer rotor generator and non-metal bearing. Further, the pouring technique mentioned earlier was also used to seal the generator stator coils instead of a moving sealed unit on the main shaft, and a water lubrication rotor bearing. This device is being tested in Zhejiang University test site (Fig.14).

Ocean University of China (OUC) which started marine energy research in 2006, initially concentrated on vertical axis turbine technologies, building and testing a 


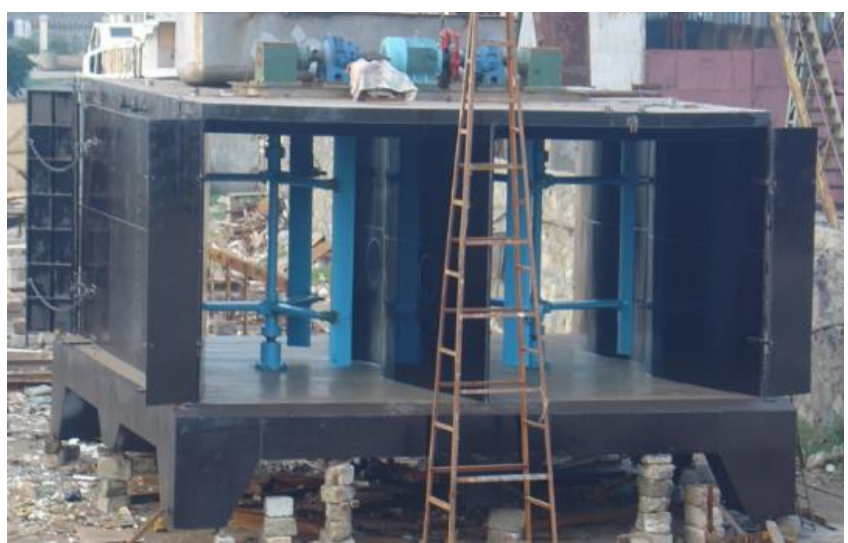

Fig.20. $2 * 20 \mathrm{~kW}$ Wanxiang II turbine.

$5 \mathrm{~kW}$ turbine with flexible blades in 2008 [40]. In 2009, OUC moved into horizontal axis turbine research and developed a $20 \mathrm{~kW}$ ducted horizontal axis turbine prototype [41, 42]. The duct was aimed at enhancing power capture. The research also covered blade design, the effect of blade shape and the number of blades per turbine on the performance, Fig.15.

In 2013 OUC also developed two $50 \mathrm{~kW}$ horizontal axis turbines rated at flow speed of $1.5 \mathrm{~m} / \mathrm{s}$ with a joint electrical pitch system (Fig.16) [43]. The turbines were part of a $500 \mathrm{~kW}$ hybrid micro-grid project being commissioned by China National Offshore Oil Corporation (CNOOC) and supported by Chinese Marine Renewable Energy Special Fund. The sea trials of the $2 \times 50 \mathrm{~kW}$ grid-connected gravity-foundationbased turbines started in 2013. The trails were abandoned after one month of operation due to sealing problems at the location between electrical cable and nacelle [44].

Harbin Electrical Corporation (HEC), who is engaged in the design and manufacture of the main components of hydropower and thermal power plants in China, started research on marine current energy conversion technologies in 2010. Its first $10 \mathrm{~kW}$ horizontal axis direct-drive turbine with a diffuser was developed and tested at sea jointly with Harbin Engineering University (HEU) in 2011 (Fig.17) [36]. The development was also supported by the Chinese Marine Renewable Energy Special Fund with the aim of bringing mature hydropower plant technologies to marine energy. HEC developed a fixed pitch $300 \mathrm{~kW}$ marine current turbine with a semi-direct drive gearbox with a large nacelle (diameter about 2.7 meters) like the bulb-type hydropower unit, which allowed workers to work inside (Fig.18). In 2019, the turbine was tested in off-grid mode at the Zhejiang University test site (Fig.9). The turbine started at $0.51 \mathrm{~m} / \mathrm{s}$, and had a reported total efficiency (from kinetic energy to electricity) of about 0.37 [45]. Because of the large nacelle and metal blades, the weight of device is above 200 tons.

LHD company developed its $3^{\text {rd }}$ generation $300 \mathrm{~kW}$ horizontal axis turbine in 2018 [46]. Unfortunately, there is no available test data reported to date. Its first two

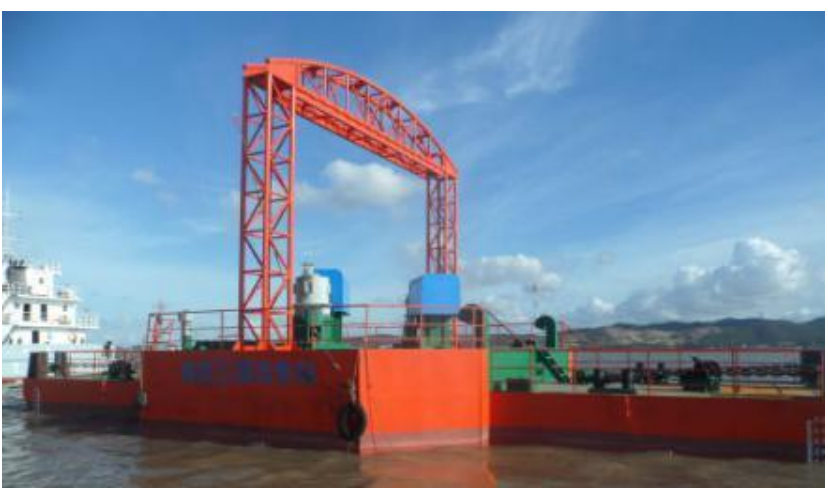

Fig.21. Haineng III platform for the $2 * 300 \mathrm{~kW}$ turbines.

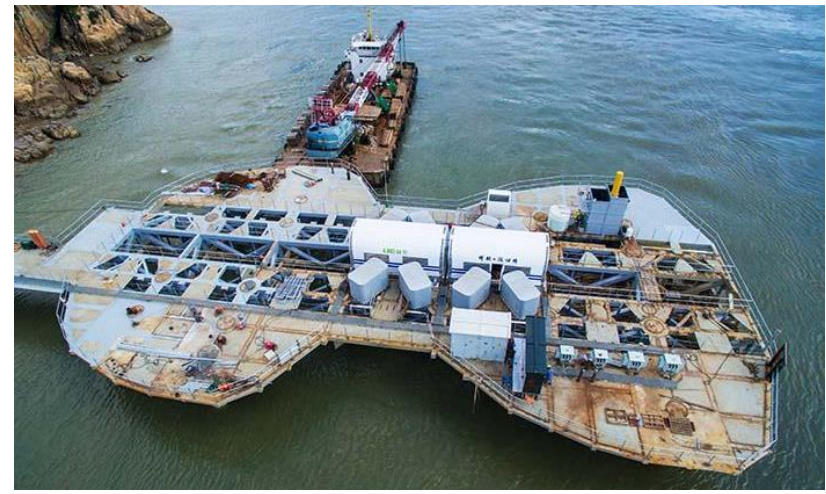

Fig.22. Marine current energy station by LHD [50].

generation devices adopted vertical axis turbine which will be reported in the next section.

In addition, the Institute of Electrical Engineering (IEE) of the Chinese Academy of Sciences (CAS) developed a rim-type direct-driven horizontal axis marine current turbine $(2 \times 2.5 \mathrm{~kW})$ supported by the Chinese Marine Renewable Energy Special Fund (Fig.19). The turbines were tested near Xixuan Island Zhoushan city in July 2016. The developer reported a starting speed of about $0.35 \mathrm{~m} / \mathrm{s}$ [47] and the conversion efficiency was about $40 \%$ [48]. The design principle is similar to that of Openhydro in Ireland [49], with the main shaft bearings located around the rims, with the inner rotor being supported by them. Its disadvantage is that the generator size will get larger with the increasing power capability, and then the manufacture of bearing, pitch actuator and field installation, will be problematic.

\section{B. Vertical axis turbine technologies}

The research on vertical axis marine current turbines in China started in 1980s, but at a slow pace of technology development partly due to its low efficiency and imbalance of load distribution on the turbine. However, such turbine technology has the advantage of operating in bi-directional flow without a pitch control system, no need for underwater sealed unit, which has attracted some institutions to be engaged in this technology type of research in China. Below we highlight some typical prototypes developed in recent years.

Harbin Engineering University (HEU) is the first institution to research vertical axis marine current turbines in China and has been engaged in it for over 30 


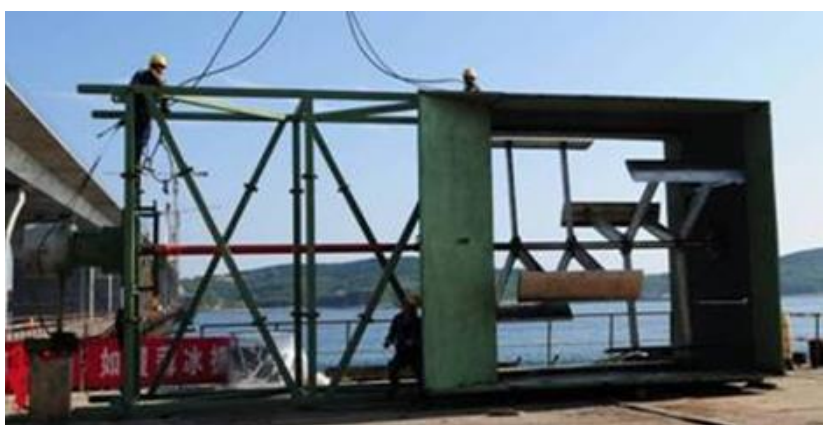

Fig.23. Vertical axis marine current turbine by DUT.

years. The floating $70 \mathrm{~kW}$ Wanxiang I and gravity-based $40 \mathrm{~kW}$ Wanxiang II (twin turbine, Fig.20) were tested at sea in Guishan channel of Zhoushan in 2002 and in Daishan in 2005 respectively. The $70 \mathrm{~kW}$ turbine used hydraulic power train system. A $2 \times 150 \mathrm{~kW}$ Haineng I (in 2012) and $2 \times 100 \mathrm{~kW}$ Haineng II (in 2013) were developed under the supports of 863 programme and National Science-Technology Support Plan respectively [40]. The $2 \times 100 \mathrm{~kW}$ turbines used two direct-drive horizontal axis turbines and were also part of the CNOOC micro grid $500 \mathrm{~kW}$ project mentioned earlier. The largest turbine to date was developed by HEU was named Haineng III. It consists of two $300 \mathrm{~kW}$ vertical axis marine current turbines (Fig.21) funded by the Chinese Marine Renewable Energy Special Fund. The turbines were deployed in Guishan Channel of Zhoushan in December 2013 and operated for more than 20 months. No operational data was made public.

Another vertical axis marine current turbine array was constructed by LHD company located in Zhoushan city, Zhejiang Province, which started their marine current energy research in 2009. The turbine is different from the above-mentioned devices, having a large concrete support platform similar to the hydropower dam plant, as can be seen in Fig.22. The platform constituted a tidal fence providing 7 test berths which can support a total capacity of 3.4 MW. LHD first gridconnected turbines began to operate in August 2016 [48], including two $200 \mathrm{~kW}$ and two $300 \mathrm{~kW}$ vertical axis marine current turbines. By the end of 2019 site deployment increased with the addition of one $400 \mathrm{~kW}$ turbine and one latest $3^{\text {rd }}$ generation $300 \mathrm{~kW}$ horizontal axis turbine. However, due to some commercial issues no further data on these turbines were reported with exception of the total generated electricity close to $1 \mathrm{GWh}$ by the end of 2018 [50].

Another player engaged in the vertical axis marine current turbines is the Dalian University of Technology (DUT) who tested a $15 \mathrm{~kW}$ VAMCT (Fig.23) which achieved a maximum power output of $8 \mathrm{~kW}$ with the total conversion efficiency $25 \%$ [51]. Its novelty is adopting a co-axial twin rotor with water lubricating bearing. In order to improve its starting performance, the two rotors have a staggered arrangement and the fix structure was designed to eliminate vortex shedding and improve the flow state around the turbines [52]. A

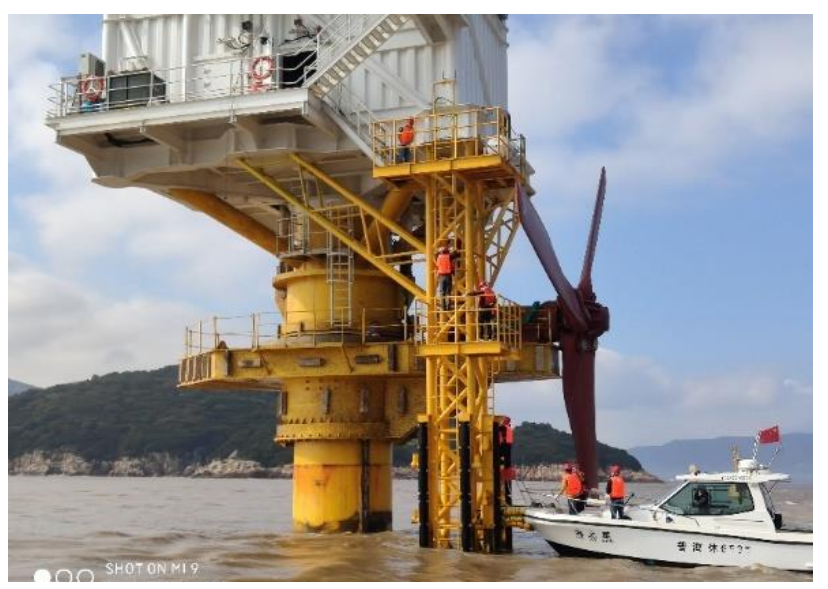

Fig.24. Test site configuration by CTGC.

special low speed Permanent Magnetic Synchronous Generator (PMSG), whose magnetic pole was sealed to resist the corrosion, was designed to improve its efficiency.

\section{Summary of turbine development}

Through the description above, some marine current energy conversion technologies went through sea trials phases. However, long operation time is needed to quantify and validate their performance and commercialisation prospect (related to the technology readiness level and development cost). In addition, the available limited resource intensity at test sites is another factor constraining turbines capacity to hundreds of kilowatts. The latter is also perceived a good choice in China reflecting its limited resource intensities.

\section{Marine energy ocean test sites in China}

The need for the construction of test sites was firstly put forward in 2013 by State Oceanic Administration, as a result of larger turbines coming on stream such as the $300 \mathrm{~kW}$ machines mentioned earlier. In 2015, China Three Gorges Corporation (CTGC) was granted a project to construct a marine current energy test field in Zhoushan, Zhejiang. The test field was scheduled to be divided into two functional areas, pilot scale demonstration area and testing area, with a targeted total capacity of around $1 \mathrm{MW}$. The demonstration area will provide at least 6 test berth and the testing area will provide 3 test berths. These areas are located in the east of Zhoushan island (see below for further details). Both sites were planned to be grid connected with one booster station to be constructed in each area, to step-up the site voltage from $690 \mathrm{~V}$ to $10 \mathrm{kV}$, then through submarine cable, transfer the electricity to an existing substation onshore. Unfortunately, the necessary permission was not granted until late around 2018/19. To date at this site, the first $500 \mathrm{~kW}$ horizontal axis turbine has been deployed and is currently being commissioned prior to full operation. Considering the sea conditions at the site, a pile structure to receive the turbines was adopted (Fig.24). 
Another test site is the location of ZJU turbines mentioned earlier. Under the support of financial fund from 2010, Zhejiang University has built the test field in Zhoushan, Zhejiang Province. The site consists of four floating test berths (Fig.9), two onshore voltage transformers and can accept turbine capacities of $75 \mathrm{~kW}$, $150 \mathrm{~kW}$ and $1 \mathrm{MW}$ (Fig.9).

The test station, located in Zhoushan, Zhejiang Province, is a part of Jintang channel which is one of three famous channels with huge tidal current energy (Fig.25). The channel is about 250 meters wide and about $500 \mathrm{~m}$ long with a maximum depth about 30 meters in the middle of channel. The seabed consists of fully weathered sandstone, so it's soft requiring gravitybased anchors to be used to fix the floating platforms. Due to the constraint presented by the islands, the maximum velocity is about $3 \mathrm{~m} / \mathrm{s}$. Further site characteristic in term of velocity distribution for the 3 turbine types is given in Fig.9 is shown in Fig.26.

To date, this test site has provided test services for the GUPC, HEC and HZJH. This site is also configurable and can provide opportunities to study the array configuration of marine current turbines in-situ.

In addition, and as mentioned earlier, the LHD company has completed its concrete foundation for its test site, which is able to provide 7 test berths, total capacity of $3.4 \mathrm{MW}$, for pilot scale marine current turbines testing at different scales. However, this site currently seems to have no interest of providing test services, which rather puzzling for such a flexible facility.

Lastly, in 2019, a comprehensive sea test site was being planned in Weihai Shandong by SOA and Weihai regional government, which was aimed to provide supports to the ocean technologies and promote their applications, including ocean equipment, marine energy devices [53]. The planned test station has a budget of 459 million RMB (US\$68.5 million) and was scheduled to be finished in 5 years [54]. One of the main functions of this test site is also to provide test berths for wave energy converters (not available at other test sites) and low velocity marine current turbines.

\section{CONCLUSIONS AND FUTURE PROSPECTS}

This work provides an overview of Chinese policy of marine current energy as well as the current status of its conversion technology. Over the last 15 years, great strides have been made to propel Chinese marine current energy technologies to pilot scale and a pathway to commercialisation. This came out on the back of supports of the Chinese central and regional governments. Tens of medium scale turbines (from $60 \mathrm{~kW}$ to $650 \mathrm{~kW}$ ) including horizontal axis turbines and vertical axis turbines have been deployed with some good results on progress. In addition to overall turbines' performances, the scope of sea testing also covered key technologies, such as blade design, fabrication, semi-
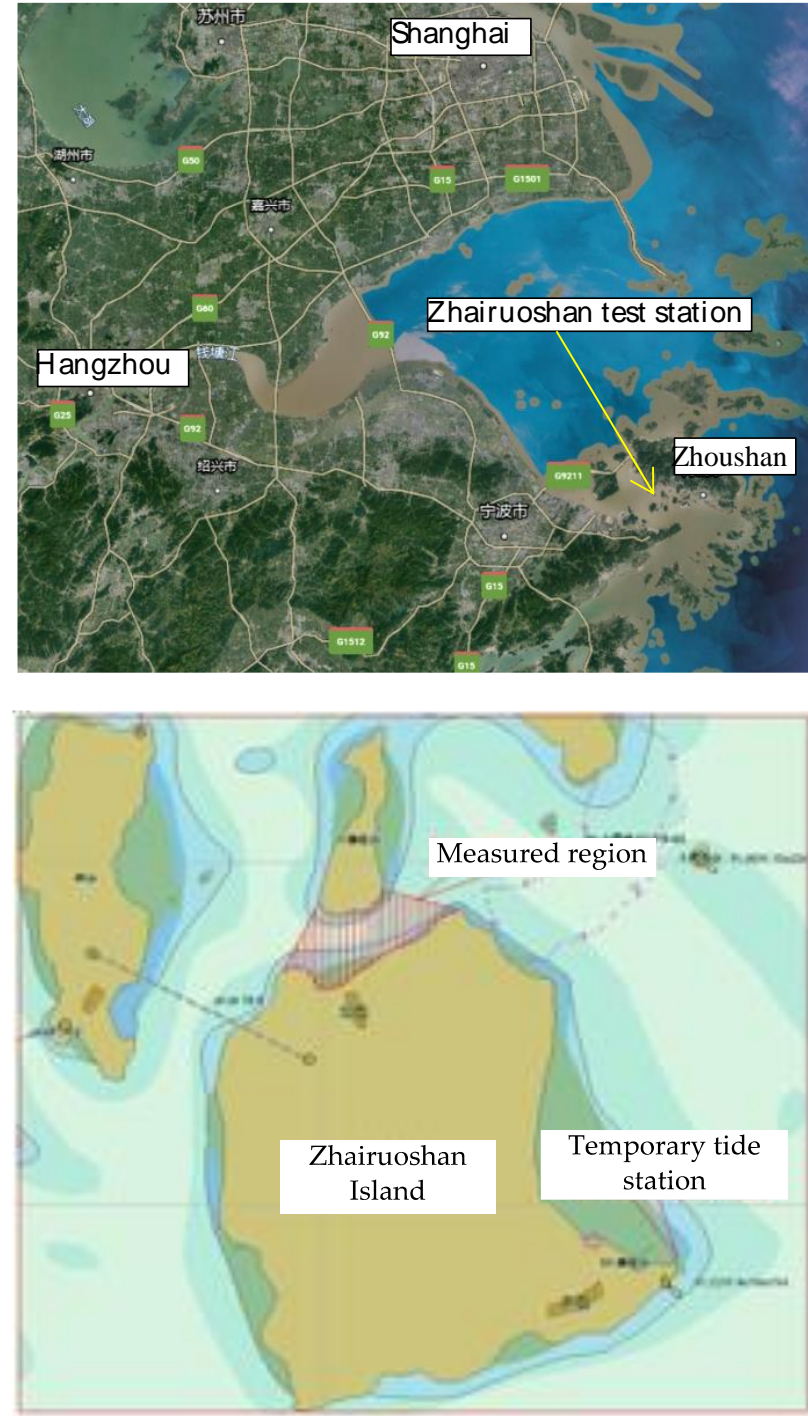

Fig. 25. Zhoushan, Zhejiang test site showing location map (top) relative to other cities in East China. The test site details and the region where measure data given in Fig.26 is shown at the (bottom).

direct driven powertrain with high reliability and efficiency, hydraulic pitch control technology, sealing techniques and operation \& maintenance of marine current turbines. This allow maturing of technology development, especially those associated with the success achieved in $300 \mathrm{~kW}$ and $650 \mathrm{~kW}$ turbines which are strong candidates for commercialisation in China and elsewhere.

The work also highlighted the role of the test sites in such developments which in addition to other needed policy and funding support are likely to enhance the prospects for further development leading to commercialisation. However, before commercialisation, much more development work is needed, including the long-term verification of design and components, operation and maintenance experience.

Looking into the near future, it is anticipated that megawatt scale turbines are likely to be constructed and tested in China. However, one of the barriers for large scale roll out is the low intensity marine current resource around China waters as compared to the good sites in 

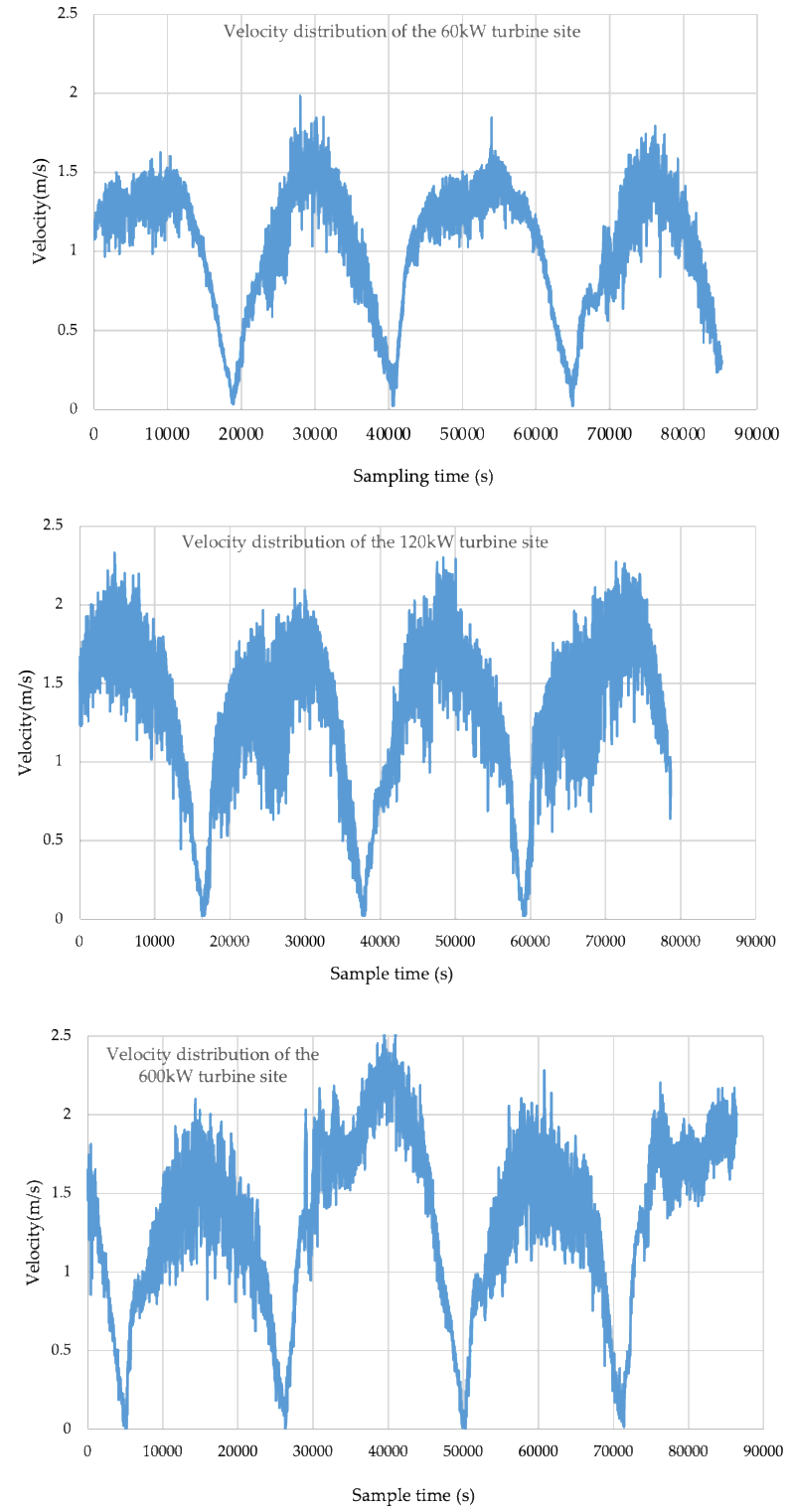

Fig.26 Zhoushan, Zhejiang test site (Fig.25) showing measured velocities where the $60 \mathrm{~kW}, 120 \mathrm{~kW} \& 600 \mathrm{~kW}$ turbines were tested.

Europe and elsewhere. Nevertheless, China is likely be looking at markets in South East Asia (SEA) where the resources are better, but the thrust will mainly be concentrated on turbines capacities in the $100 \mathrm{~s}$ of kilowatts not only to take advantage of the local Chinese resources but also explore niche island electrical power supply markets around SEA region. In addition, a potential application for marine current turbines is perhaps in sea aquaculture, sea water desalination and hydrogen production as a stepping-stone to commercialisation [55].

The drafting of $14^{\text {th }}$ five year plan (years 2021-2025) is currently being carried on by local governments and sectors such as NEA [56]. In the coming five years, augmenting the proportion of non-fossil energy in the energy supply mix of China will be the focus and the goal is expected to be $17.5 \%$ by 2025 ( 15\% in 2020) and $\sim 25 \%$ by $2030[57,58]$. As projected, the grid parity of wind energy and solar energy is expected to be achieved in next 5 years or earlier, and large-scale development and utility scale renewable energy supply will be main thrust for development and achieving the set targets in the plan. At the same time, marine energy (wave and tidal) as part of the ocean energy platform will undoubtedly be considered especially as a promising renewable energy resources in some coastal provinces (Table 1). Hence, marine current or tidal energy has a promising but a long prospect for large scale development in China, however some potential niche applications (isolated islands and water desalinisation) are likely to be supported in the medium term [55].

\section{ACKNOWLEDGEMENT}

This work forms part of the activities of the Energy and Climate Change Division and the Sustainable Energy Research Group in the Faculty of Engineering and Physical Sciences at the University of Southampton (www.energy.soton.ac.uk), UK. Prof Lui has spent 12 months conducting research with the ECCD team and this work is part of the main outcomes of the secondment. In addition to the main sources of support mentioned in the footnote to the first page, the work was also supported by EPSRC grants EP/N010779/1, CityWide Analysis to Propel Cities towards Resource Efficiency and Better Wellbeing; EP/K012347/1 Efficient VERsatile Energy Services Solution Through DC; EP/R030391/1 Fortis Unum: Clustering Mini Grid Networks to Widen Energy Access and Enhance Utility Network Resilience; and Innovate UK Project Number: 40582 Demand Side Renewable Agriculture Business Led Enterprise.

\section{REFERENCES}

[1] A. S. Bahaj and L. E. Myers, "Fundamentals applicable to the utilisation of marine current turbines for energy production," Renewable Energy, vol. 28 , no. 14, pp. 2205-2211, 2003/11/01/2003, doi: https://doi.org/10.1016/S0960-1481(03)00103-4.

[2] A. S. Bahaj, "Marine current energy conversion: the dawn of a new era in electricity production," Philosophical Transactions of the Royal Society A: Mathematical, Physical and Engineering Sciences, vol. 371, no. 1985 , p. 20120500, 2013/02/28 2013, doi: 10.1098/rsta.2012.0500.

[3] A.S.Bahaj, "Generating electricity from the oceans," Renewable and Sustainable Energy Reviews, vol. 15, pp. 3399-3416, 2011.

[4] SIMEC Atlantis.

"MeyGen." https://simecatlantis.com/projects/meygen/ (accessed May 2021.

[5] OES, "Annual report 2019," The Executive Committee of Ocean Energy Systems, 2019.

[6] reNews. "Atlantis to decommission SeaGen." https://renews.biz/44355/atlantis-todecommission-seagen/ (accessed May, 2021).

[7] Andritz Hydro. "MeyGen - Scotland." https://www.andritz.com/hydro- 
en/hydronews/hy-hydro-news-30/hy-news-30-14meygen-scotland-hydro (accessed.

[8] D.S.Coles, L.S.Blunden, and A.S.Bahaj, "Turbulent Flow Within Multi-Row Tidal Stream Turbine Arrays," in Proceedings of the 12th European Wave and Tidal Energy Conference (EWTEC), Cork, Ireland, 27th August - 2nd September 20172017.

[9] D.S.Coles, L.S.Blunden, and A.S.Bahaj, "Assessment of the energy extraction potential at tidal sites around the Channel Islands," Energy Conversion $\mathcal{E}$ Management, vol. 124, pp. 171-186, 2017.

[10] A.S.Bahaj, W.M.J.Batten, and G.McCann, "Experimental verifications of numerical predictions for the hydrodynamic performance of horizontal axis marine current turbines," Renewable energy, vol. 32, no. 15, pp. 2479-90, 2007, doi: 10.1016/j.renene.2007.10.001.

[11] A.S.Bahaj, L.S.Blunden, and A.A.Anwar, Model Templates for Reporting and Supplementary Information for the Tidal-current Energy Device Development and Evaluation Protocol. University of Southampton, Sustainable Energy Research Group, 2008.

[12] A.S.Bahaj and L.E.Myers, "Shaping array design of marine current energy converters through scaled experimental analysis," Energy, vol. 59, pp. 83-94, 2013, doi: 10.1016/j.energy.2013.07.023.

[13] A.S.Bahaj, A.F.Molland, J.R.Chaplin, and W.M.J.Batten, "Power and thrust measurements of marine current turbines under various hydrodynamic flow conditions in a cavitation tunnel and a towing tank," Renewable energy, vol. 32, no. 3, pp. 407-426, 2007.

[14] L.S.Blunden and A.S.Bahaj, "Flow through large arrays of tidal energy converters: is there an analogy with depth limited flow through vegetation," in Proceedings World Renewable Energy Congress (WREC X), 2008, pp. 1091-1096.

[15] H. Liu, S. Ma, W. Li, H. Gu, Y. Lin, and X. Sun, "A review on the development of tidal current energy in China," Renewable and Sustainable Energy Reviews, vol. 15, pp. 1141-1146, 2011.

[16] D. Li, S. Wang, and P. Yuan, "An overview of development of tidal current in China: Energy resource, conversion technology and opportunities," Renewable and Sustainable Energy Reviews, vol. 14, no. 9, pp. 2896-2905, 2010, doi: 10.1016/j.rser.2010.06.001.

[17] C. Wang and W. Lu, Analysis methods and reserves evaluation of ocean energy resources. Beijing: Ocean Press, 2009.

[18] Y. Zhang, Z. Lin, and Q. Liu, "Marine renewable energy in China:Current status and perspectives," Water Science and Engineering, vol. 7, no. 3, pp. 288305, 2014.

[19] S. Wang, P. Yuan, D. Li, and Y. Jiao, "An overview of ocean renewable energy in China," Renewable and Sustainable Energy Reviews, vol. 15, no. 1, pp. 91-111, 2011, doi: 10.1016/j.rser.2010.09.040.
[20] Discover Hangzhou. "The world's first ocean tidal current power station built by riverside." https://m.sohu.com/a/338052142 120209852 (accessed May, 2021).

[21] National Energy Administration of China. "Summary of Reply to Proposal No. 3110 of the Second Meeting of the 13th National Committee of the

CPPCC."

http://zfxxgk.nea.gov.cn/auto87/201910/t20191009 3874.htm (accessed May, 2021).

[22] National Development and Reform Commission. "Notice of the National Development and Reform Commission and the National Energy Administration on Issuing the "Energy Production and Consumption Revolution Strategy (20162030)"." http://www.chinanengyuan.com/news/107560.html (accessed May, 2021).

[23] National Energy Administration of China, "Energy Technology Innovation for 13th Five-Year Plan," 2016.

[24] Ministry of Science and Technology. "The "Twelfth Five-Year" National 863 Project "Research on Key Technologies of Ocean Current Power Generation and Island New Energy Power Supply" passed acceptance."

http://www.most.gov.cn/kjbgz/201710/t20171030 135873.htm (accessed May, 2021).

[25] Zhejiang News. "Zhoushan City's "14th Five-Year Plan" and 2035 long-term goals recommendations released."

https://zj.zjol.com.cn/news.html?id=1593388 (accessed May, 2021).

[26] (2018). Proposal guidelines of renewable energy and hydrogen key projects in 2018.

[27] P. Wei, M. Changlei, and W. Haifeng, Annual report of Chinese ocean energy development in 2019 (in Chinese). Beijing: China Ocean Press, 2019.

[28] Z. University, "Technical reports - research on arrays of marine current turbines," 2015.

[29] X. Zhang, "Currents to power generation and the development of simulator," Master, Northeast Normal University, 2009.

[30] S. Ma, "Study on energy conversion efficiency and power control of horizontal axis tidal current energy conversion systems," Doctor, Zhejiang University, 2011.

[31] Y. Liu et al., "Utilization status and suggestions on development of tidal current energy in Zhoushan area," Ocean exploitation and management, no. 8, pp. 77-79, 2016.

[32] H. Liu, H. Zhou, Y. Lin, W. Li, and H. Gu, "Design and test of $1 / 5$ th scale horizontal axis tidal current turbine," China Ocean Engineering, vol. 30, no. 3, pp. 407-420, 2016, doi: 10.1007/s13344-016-0027-5.

[33] Q. Xu, H. Liu, Y. Lin, X. Yin, W. Li, and Y. Gu, "Development and experiment of a $60 \mathrm{~kW}$ horizontal-axis marine current power system," Energy, vol. 88, pp. 149-156, 2015, doi: 10.1016/j.energy.2015.04.018. 
[34] Q. Xu, W. Li, Y. Lin, H. Liu, and Y. Gu, "Investigation of the performance of a stand-alone horizontal axis tidal current turbine based on in situ experiment," Ocean Engineering, vol. 113, pp. 111-120, 2016, doi: 10.1016/j.oceaneng.2015.12.051.

[35] Y. Gu, H. Liu, W. Li, Y. Lin, and Y. Li, "Integrated design and implementation of $120-\mathrm{kW}$ horizontalaxis tidal current energy conversion system," Ocean Engineering, vol. 158, pp. 338-349, 2018.

[36] Y. Bai, M. Du, Q. Zhou, H. Meng, and H. Wu, "Proceeding of tidal current energy conversion system," Ocean exploitation and management, no. 3, pp. 57-61, 2016.

[37] B. Wu, "Research on the horizontal axis tidal stream turbine," D, Northeast Normal University, 2015.

[38] D. Xia, "Key technologies research and demonstration in ocean energy development," China Science and Technology Achievements, no. 22, pp. 76-79, 2013.

[39] Hangzhou Jianghe Hydropower Technology Co. Ltd. "State Oceanic Administration's special fund project-300kw horizontal axis tidal energy generator set." http://www.hjhe.cn/abc/ (accessed May, 2021).

[40] W. Gao, "Study on hydrodynamic performance of self-adapt floating tidal current energy generating device," Master, Ocean University of China, 2014.

[41] S. Wang, K. Wang, P. Yuan, X. Yu, and X. Wang, "Study on twist angle and chord length distribution of horizontal axis tidal current turbine," Piriodical of Ocean University of China, vol. 48, no. 10, 2018.

[42] S. Wang, S. Xu, P. Yuan, J. Tan, and C. Chen, "Study on hydrodynamic performance of diffuser for axial flow marine current energy converter," Acta Energiae Solaris Sinica, vol. 35, no. 6, pp. 10981104, 2014.

[43] W. Li, H. Liu, and Y. Lin, Technologies and Equipments of Ocean Current Power Generation Beijing: Science Press, 2020.

[44] "Summary report of 500kW ocean energy project for isolated power supply", 2014.

[45] Heilongjiang People's Livelihood Official account. "Harbin Electric successfully developed China's largest-capacity tidal current generating set." https://baijiahao.baidu.com/s?id=16554804351030 $\underline{63439}$ (accessed May, 2021).

[46] Daishan County Economic and Information Bureau. "Third generation unit of modular ocean tidal power generation project successfully launched into the sea." http://www.daishan.gov.cn/art/2019/1/11/art 138 2882 29383173.html (accessed May, 2021).
[47] ScienceNet.cn. "Project "Design and experimental analysis of rim-driven marine current power generation system" received expert acceptance." http://news.sciencenet.cn/htmlnews/2017/2/36903 6.shtm (accessed May, 2021).

[48] OES, "Annual report ocean energy systems 2016," 2016.

[49] J. Ives, "Openhydro: Path to Commercialisation," in ICOE 2014 International conference on ocean energy, Halifax, NS Canada, Nov.4-6 2014.

[50] AEIC Academic Exchange Center. "Annual power generation capacity can reach 1 million $\mathrm{kWh}$, and the installation of the third-generation LHD ocean tidal energy modular generator set is completed!" https://www.keoaeic.org/consultation/1862.html (accessed May, 2021).

[51] H. Zhang, "Design and analysis of DUTTCT_H120 horizontal axis turbine blade," M, Dalian University of Technology, 2016.

[52] Dalian University of Technology. "Dagong tidal current energy experimental power station completed on Changshan Island to generate electricity."

http://panjin.dlut.edu.cn/info/1028/7687.htm (accessed May, 2021).

[53] Ministry of Natural Resources. "The first national marine comprehensive test site will be built in Weihai."

http://www.mnhr.gov.cn/dt/hy/201907/t20190701 2443365.html (accessed May, 2021).

[54] H. X. Zhang, Jie. "The first national shallow sea comprehensive marine test site settled in Weihai." iqilu.com.

http://news.iqilu.com/shandong/yuanchuang/201 4/1108/2204511.shtml (accessed May, 2021).

[55] J. J. Koschikowski, Verena; Kec, Thomas; Hussein, Noha Saad, "RENEWABLE DESALINATION: TECHNOLOGY OPTIONS FOR ISLANDS," 2015. [Online]. Available: https://irena.org/publications/2015/Dec/Renewabl e-Desalination-Technology-Options-for-Islands

[56] solarF. "Demonstration Projects in the 14th FiveYear Plan for the Development of Renewable Energy."

http://www.solarf.net/news/headline/202006/1120 3.html (accessed May, 2021).

[57] Polaris Power Network. "The Energy Administration issued a document to clarify the key points of the "14th Five-Year Plan" for renewable energy development." http://news.bjx.com.cn/html/20200415/1063610.sh $\underline{\mathrm{tml}}$ (accessed May, 2021).

[58] Petroleum Business News. "Analysis: What does the Chinese leadership's goal of "non-fossil energy consumption to reach $25 \%$ by 2030 " mean?" https://view.inews.qq.com/a/20201220A09M7700 (accessed May, 2021). 